\title{
Analisis Framing Reuni 212 Pada Acara Indonesia Lawyer Club di TVOne
}

\author{
Nur Mahdi, M. Ferdinan Sembiring*) \\ Program Studi Ilmu Komunikasi Universitas Muhammadiyah Sumatera Utara dan Jurnalis Harian \\ Waspada, Sumatera Utara, Indonesia \\ Koresponden: yogensa@gmail.com
}

\begin{abstract}
Abstrak
Tujuan dalam kajian penelitian ini adalah peneliti ingin membingkai persoalan Reuni Akbar 212 di dalam talk show Indonesia Lawyer Club di TVOne. Bagaimana para narasumber menyikapi persoalan tersebut menggunakan analisis framing. Metode penelitian yang digunakan pada penelitian ini adalah metode penelitian kualitatif dengan pendekatan analisis framing model Robert N. Entman.. Hasil penelitian ini adalah Reuni 212 adalah sebuah acara yang diselenggarakan oleh Presidium Alumni 212 di lapangan Monas untuk merayakan satu tahun Aksi 212 yang menuntut pengambilan tindakan hukum terhadap Gubernur DKI Jakarta non aktif, Basuki Tjahja Purnama (Ahok). Reuni 212 diselenggarakan pada tanggal 02 Desember 2017 sebagai bentuk aksi propaganda positif yang dilaksanakan masyarakat umat Islam untuk menunjukkan sebuah kebenaran dan menimbulkan rasa kepercayaan yang begitu besar.
\end{abstract}

Kata kunci: Framing, Talk Show, Reuni 212

\section{Abstract}

The purpose of this research study is that the researcher wants to frame the issue of Reunion Akbar 212 in the Indonesian Lawyer Club talk show on TVOne. How the speakers responded to the problem using framing analysis. The research method used in this study is a qualitative research method with the Robert N. Entman framing analysis approach. The results of this study are Reunion 212 is an event organized by the 212 Alumni Presidium in Monas field to celebrate one year of Action 212 which requires action taking the law against the non-active Governor of DKI Jakarta, Basuki Tjahja Purnama (Ahok). The 212th reunion was held on December 2, 2017 as a form of positive propaganda carried out by the Muslim community to show the truth and create a great sense of trust.

Keywords: Framing, Talk Show, Reunion 212

\section{Pendahuluan}

Reuni 212 adalah sebuah acara yang diadakan oleh Presidium Alumni 212 di Lapangan Monas pada tanggal 2 Desember 2017 untuk merayakan satu tahun Aksi 212 yang menuntut pengambilan tindakan hukum terhadap Gubernur DKI Jakarta nonaktif pada masa itu, Basuki Tjahaja Purnama. Aksi 212 merupakan sejarah besar bagi umat Islam Indonesia. Maka setiap tahun juga sebanyak tujuh juta orang ini akan berkumpul dan bersilaturahmi tanpa memandang kelompok, golongan, mazhab, dan agama. Ini menguatkan komitmen bahwa umat Islam menjadi yang terdepan menjaga kerukunan antar umat beragama dengan prinsip saling menghargai dan menghormati.

Bukan hanya itu Aksi 212 juga mempunyai dampak yang luar bisa bagi sebagian besar umat muslim di Indonesia dalam melihat pentingnya persatuan umat dalam bingkai NKRI. Aksi 212 telah menyatukan hati, menyamakan kata, dan merapatkan barisan umat Islam untuk menjaga NKRI. Apapun mazhabnya, apapun organisasinya, Aksi 212 telah menyatukan persepsi dan hati sebagian besar umat Islam untuk mengubah energi kerumunan menuju energi kekuatan di berbagai bidang terutama ekonomi dan sosial.

Media massa atau Pers adalah suatu istilah yang mulai digunakan pada tahun 1920-an untuk mengistilahkan jenis media yang secara khusus dirancang untuk mencapai masyarakat yang sangat luas. Dalam pembicaraan sehari-hari istilah ini sering disingkat menjadi media. Media 
adalah segala bentuk dan saluran yang digunakan untuk menyampaikan informasi atau pesan. Kata media berasa 1 dari kata latin, merupakan bentuk jamak dari kata "medium". Secara harfiah kata tersebut mempunyai arti "perantara" atau "pengantar", yaitu perantara sumber pesan (source) dengan penerima pesan (receiver). Jadi, dalam pengertian yang lain, media adalah alat atau sarana yang dipergunakan untuk menyampaikan pesan dari komunikator kepada khalayak. Banyak ahli dan juga organisasi yang memberikan batasan mengenai pengertian media.

Stasiun televisi swasta TVOne, meliput dan menayangkan secara live dan ekslusif aksi reuni akbar 212 tersebut. semua meliput secara langsung acara yang digelar tersebut. Kemudian salah satu siaran televisi talk show yang membahas dan mengulik tentang reuni akbar 212 adalah talk show Indonesia Lawyer Club. Indonesia Lawyer Club sendiri adalah acara talkshow yang disiarkan di TV One. Acara ini menampilkan dialog mengenai masalah hukum dan kriminalitas selama 210 menit dan dipandu oleh Karni Ilyas. Acara ini disiarkan setiap hari Selasa pukul 20:00 WIB dan Minggu pukul 19:30 WIB. Di dalam talk show Indonesia Lawyer Club, masih menyisakan perdebatan terhadap reuni akbar 212 tersebut. Banyak artikel, komentar dari para orang-orang yang berperanguh terhadap aksi reuni akbar tersebut. Sebagian masyarakat yang tidak menyetujui menganggap Reuni Akbar 212 tersebut sebagai tindakan intoleransi, sedangkan sebagian masyarakat yang menyutujui menganggap bahwa ini adalah aksi silaturahmi yang baik untuk seluruh umat islam di Indonesia. Dalam hal ini, peneliti membingkai persoalan Reuni Akbar 212 di dalam Talk Show Indonesia Lawyer Club. Bagaimana para narasumber menyikapi persoalan tersebut menggunakan analisis framing. Analisis framing adalah salah satu metode analisis media Secara sederhana. Framing adalah membingkai sebuah peristiwa, atau dengan kata lain framing digunakan untuk mengetahui bagaimana perspektif atau cara pandang yang digunakan wartawan atau media massa ketika menyeleksi isu dan menulis berita.

\section{Pengertian Teori Framing}

Menurut Sobur (2006:162), Konsep framing telah digunakan secara luas dalam literatur ilmu komunikasi untuk menggambarkan proses penseleksian dan penyorotan aspek-aspek khusus sebuah realita oleh media. Dalam ranah studi komunikasi, analisis framing mewakili tradisi yang mengedepankan pendekatan atau perspektif multidisipliner untuk menganalisis fenomena atau aktivitas komunikasi. Analisis framing digunakan untuk membedah cara-cara atau ideologi media saat mengkonstruksikan fakta.Analisis ini mencermati strategi seleksi, penonjolan, dan tautan fakta ke dalam berita agar lebih bermakna, lebih menarik, lebih berarti atau lebih diingat, untuk menggiring interpretasi khalayak sesuai perpektifnya. Proses ini berhubungan dengan penyajian fakta yang akan dipilih kepada khalayak. Cara penyajian itu meliputi pemilihan kata, kalimat, preposisi, gambar dan foto pendukung yang akan ditampilkan. Tahap menuliskan fakta itu berhubungan dengan penonjolan realitas. Aspek tertentu yang ingin ditonjolkan akan mendapatkan alokasi dan perhatian yang lebih besar untuk diperhatikan dan mempengaruhi khalayak dalam memahami suatu realitas. kata kunci dari analisis framing adalah seleksi isu, pola penonjolan dan menulis berita. Analisis framing berpusat pada produksi berita oleh media. Penonjolan merupakan sebuah produk interaksi antara teks dan penerima, maka kehadiran frame dalam teks tidak menjamin pengaruhnya terhadap pemikiran khalayak (Entman, 1993 dalam Siahaan, 2001:78-79).

Menurut Bungin (2008:195), analisis framing merupakan versi terbaru dari pendekatan analisis wacana, khususnya untuk menganalisis teks media. Gagasan mengenai framing, pertama kali dilontarkan oleh Beterson pada tahun1955. Pada mulanya frame dimaknai sebagai struktur konseptual atau perangkat kepercayaan yang mengorganisir pandangan politik, kebijakan, dan wacana,serta menyediakan kategori-kategori standar untuk mengapresiasi realitas. Namun kemudian, pengertian framing berkembang yaitu ditafsirkan untuk menggambarkan proses penseleksian dan penyorotan aspek-aspek khusus sebuah realita oleh media.

Dalam perspektif studi komunikasi, analisis framing dipakai untuk membedah cara-cara atau ideologi media saat mengkonstruksi fakta. Dengan katalain, framing adalah pendekatan untuk mengetahui bagaimana perspektif atau cara pandang orang yang digunakan oleh wartawan ketika menyeleksi isudan menulis berita. Oleh karenaitu, berita menjadi manipulatif dan bertujuan 
mendominasi keberadaan subjek sebagai sesuatu yang legitimate, objektif, alamiah, wajar dan tak terelakkan, (Nurhadi, 2015:80). Pada dasarnya framing adalah metode untuk melihat cara media bercerita atas suatu realitas. ada dua esensi utama dari framing tersebut. Pertama, bagaimana peristiwa dimaknai.Ini berhubungan dengan bagianmana yang diliput dan mana yang tidak diliput. Kedua, bagaimana fakta itu ditulis Aspek ini berhubungan dengan pemakaian kata, kalimat, dan gambar untuk mendukung gagasan. Dalam analisis framing juga yang menjadi pusat perhatian adalah pembentukan pesan dari teks. Terutama, melihat bagaimana pesan/peristiwa dikonstruksi oleh media. Bagaimana wartawan mengkonstruksi peristiwa dan menyajikannya kepada khalayak pembaca, (Eriyanto, 2002:11).

\section{Model Analisis Framing Robert N. Entman}

Konsep framing oleh Entman, digunakan untuk menggambarkan proses seleksi dan menonjolkan aspek tertentu dari realitas oleh media. Framing memberi tekanan lebih pada bagaimana teks komunikasi ditampilkan dan bagian mana yang ditonjolkan atau dianggap penting oleh pembuat teks. Kata penonjolan itu sendiri dapat didefinisikan membuat informasi lebih terlihat jelas, lebih bermakna, atau lebih mudah diingat oleh khalayak.Bentuk penonjolan tersebut bisa beragam menempatkan satu aspek informasi lebih mononjol dibandingkan yang lain, lebih mencolok, melakukan pengulangan informasi yang dipandang penting atau dihubungkan dengan aspek budaya yang akrab di benak khalayak, sebab kemenonjolan adalah produk interaksi antara teks dan penerima, kehadiran frame dalam teks bisa jadi tidak seperti yang dideteksi oleh peneliti, khalayak sangat mungkin mempunyai pandangan apa yang dia pikirkan atas suatu teks dan bagaimana teks berita tersebut dikonstruksi dalam pikiran khalayak,(Eriyanto, 2002:186).

Dalam praktiknya, framing dijalankan oleh media dengan menseleksi isu tertentu dan mengabaikan isu yang lain dan menonjolkan aspek dari isu tersebut dengan menggunakan berbagai strategi wacana penempatan yang mencolok (menempatkan di headline depan atau bagian belakang), pengulangan, pemakaian grafis untuk mendukung dan memperkuat penonjolan, pemakaian label tertentu ketika menggambarkan orang atauperistiwa yang diberitakan, asosiasi terhadap simbol budaya, generalisasi, simplifikasi dan lain-lain. Semua aspek itu dipakai untuk membuat dimensi tertentu dari konstruksi berita menjadi bermakna dan diingat oleh khalayak. Framing adalah pendekatan untuk mengetahui bagaimana perspektif atau cara pandang yang digunakan oleh para wartawan ketika menseleksi isu dan menulis berita. Cara pandang atau perspektif itu pada akhirnya menentukan fakta apa yang diambil, bagian mana yang ditonjolkan dan dihilangkan, dan hendak dibawa kemana berita tersebut, (Nurhadi, 2015:91).

\section{Metode}

Metode penelitian yang digunakan pada penelitian ini adalah metode penelitian kualitatif dengan pendekatan analisis framing model Robert N. Entman. Analisis framing digunakan untuk mengkaji pembingkaian realitas (peristiwa, individu, kelompok, dan lainnya) yang dilakukan oleh media massa. Pembingkaian tersebut merupakan proses konstruksi, yang berarti realitas dimaknai dan direkonstruksi dengan cara dan makna tertentu. Robert Entman merupakan seorang ahli yang meletakkan dasar-dasar bagi analisis framing untuk studi isi media (Eriyanto, 2002: 219). Konsep Entman menjadi menarik untuk digunakan dalam meneliti kasus reuni akbar 212. Melalui konsep framing yang digunakan untuk menggambarkan proses seleksi sudah menonjolkan aspek tertentu dari realitas oleh media, dapat menghasilkan penelitian yang memberi gambaran mengenai isu dan aspek apa yang ditonjolkan oleh kedua mediaterkait kasus tersebut.

Hal tersebut disebabkan framing dapat dipandang sebagai penempatan informasiinformasi dalam konteks yang khas sehingga isu tertentu mendapatkan alokasi lebih besar dari pada isu yang lain (Eriyanto, 2002: 220). Konsep framing dari Robert Entman yang digunakan dalam menganalisis berita tentang Ahok di ILC dengan empat pendekatan yakni 1). Pendefenisian masalah (Define Problems): Bagaimana suatu peristiwa/isu dilihat?; 2).Memperkirakan masalah atau sumber masalah (Diagnose cause): Peristiwa itu disebabkan oleh apa? Apa yang dianggap sebagai penyebab dari suatu masalah? Siapa (aktor) yang dianggap sebagai penyebab masalah?; 3). 
Membuat keputusan moral (Moral Judgment): Nilai moral apa yang disajikan untuk menjelaskan masalah? Nilai moral apa yang dipakai untuk mendelegitimasi suatu tindakan?; 4). Menekankan penyelesaian (Treatment Recommendation): Penyelesaian apa yang ditawarkan untuk mengatasi masalah/isu? Jalan apa yang ditawarkan dan harus ditempuh untuk mengatasi masalah? (Eriyanto, 2002: 223-224)

\section{Hasil dan Pembahasan}

Indonesia Lawyers Club (disingkat ILC; sebelumnya bernama Jakarta Lawyers Club) adalah acara talkshow yang disiarkan di tvOne. Acara ini menampilkan dialog mengenai masalah hukum dan kriminalitas selama 210 menit dan dipandu oleh Karni Ilyas. Acara ini disiarkan setiap hari Selasa pukul 20:00 WIB.

Kasus ini bermula ketika Ahok berkunjung ke Kabupaten Adm. Kepulauan Seribu pada bulan September 2016. Kunjungan tersebut dalam rangkaProgram Kerjasama Pemprov DKI dengan Sekolah Tinggi Perikanan (STP) untuk budi daya perairan. Di dalam video yang diunggah oleh Publikasi dan Dokumentasi, Dinas Komunikasi Informasi dan Kehumasan, Pemprov DKI Jakarta, dalam pidatonya Ahok mengatakan dibohongi pakai surat Al-Maidah ayat 51. Berikut potongan script pada menit ke23.40sampai 24.57dari video tersebut : "Jadi bapak ibu gak usah khawatir, ini pemilihan kan dimajuin, jadi kalau saya tidak terpilih pun, bapak ibu saya berhentinya Oktober 2017. Jadi kalau program ini kita jalankan dengan baik pun, bapak ibu masih sempat panen sama saya, sekalipun saya tidak terpilih jadi Gubernur. Jadi saya ingin,ceritanya bapak/ibu semangat. Jadi, gak usah kepikiran ah nanti kalau gak kepilih, pasti Ahok programnya bubar. Enggak, saya sampai oktober 2017”"Jadi jangan percaya sama orang, kan bisa aja dalam hati kecil bapak ibu, nggak bisa milih saya,ya kan. dibohongi pakai surat Al Maidah 51macemmacem itu. Itu hak bapak ibu, ya, jadi kalau bapak ibu perasaangka bisa milih nih karena saya takut masuk neraka, dibodohin gitu ya, nggak papa.Karena kan panggilan pribadi bapak ibu. Program ini jalan saja, jadi bapak ibu nggak usah merasa enggak enak. Dalam nuraninya nggak bisa pilih Ahok, nggak suka sama Ahok, tapi programnya gua kalau terima, gua nggak enak dong sama dia, gua hutang budi.

\section{Reuni 212}

Jangan, kalaubapak ibu punya perasaan nggak enak nanti mati pelan-pelan lo kena struk.”

Kemudian video tersebut diunggah kembali oleh Buni Yani pada tanggal 5 Oktober 2016.Video tersebutviral di sosial media seperti berita yangditerbitkan oleh republika.co.id dengan judul: "Video Ahok: Anda Dibohongi Al-Quran Surat Al-Maidah 51Viral di Medsos", pada hari Kamis, 6 Oktober 2016, pukul 14:17 WIB oleh penulis Agung Sasongko.Setelah informasi ini menjadi konsumsi bagi khalayak karena diangkat oleh berbagai media, hingga hari ini pemberitaan pun terus bergulir. Baik mengangkat isu penistaan agama, hingga terjadinya aksi massa yang cukup besar pada tanggal 28 Oktober 2016, 4 November 2016, 2 Desember 2016, hingga penetapan Ahok menjadi tersangka oleh Kapolri seperti berita yang diterbitkan pada Rabu, 16 November 2016, pukul 10:12 WIB oleh Metrotvnews.com "Ahok Jadi Tersangka".

Diprediksi masih akan terus bergulir hingga kasus dugaan penistaan agama selesai di pengadilan.Aksi 2 Desember atau yang disebut juga Aksi 212 dan Aksi Bela Islam III terjadi pada 2 Desember 2016 di Jakarta, Indonesia di mana sedikitnya ribuan massa kembali menuntut Gubernur DKI Jakarta nonaktif, Basuki Tjahaja Purnama (Ahok), yang telah ditetapkan sebagai tersangka dalam kasus dugaan penistaan agama. Aksi ini juga dikenal dengan sebutan Aksi Damai 2 Desember. Aksi tersebut merupakan peristiwa penuntutan kedua terhadap Ahok pada tahun 2016 setelah unjuk rasa sebelumnya terjadi pada 4 November. Pada awalnya, aksi tersebut rencana diadakan pada 25 November, namun kemudian disepakati diadakan pada tanggal 2 Desember 2016. Aksi ini dilaksanakan di halaman Monumen Nasional, Jakarta. Jumlah peserta hadir berkisar antara 200 ribu (klaim polisi) hingga jutaan (klaim penyelenggara) dari bukti - bukti video yang tersebar di berbagai sosial media dan situs berbagi video melalui tangkapan kamera drone, dapat terlihat bahwa jumlah massa meluas hingga mamadati area Bundaran Hotel 
Indonesia (HI). Dalam aksi ini, sejumlah kegiatan yang dilaksanakan adalah berdoa dan melakukan shalat Jumat bersama.Presiden Joko Widodo hadir dalam acara ini dan disambut hangat oleh para peserta aksi.

Pada pembahasan peelitian ini, peneliti membahas siaran televisi TV One pada acara Indonesia Lawyer Club (ILC) yang ditanyangkan pada hari selasa, 05 Desember 2017. Adapun model framing Robertn N. Entment yang dipakai oleh penulis, akan dijabarkan pada tabel berikut ini :

Tabel 1

Analisis Framing Robert N. Entman

\begin{tabular}{|c|c|c|}
\hline No & Teori Mode Robert N. Entman & Analisis Framing \\
\hline 01 & $\begin{array}{l}\text { Pendefinisian } \\
\text { Masalah (Define Problems) }\end{array}$ & $\begin{array}{l}\text { Pada reuni } 212 \text { yang ditayangkan } \\
\text { oleh Indonesia Lawyer Club (ILC) } \\
\text { pendefinisian masalah yang dapat ditarik } \\
\text { oleh penulis adalah aksi reuni } 212 \\
\text { yang masih dipertanyakan apa } \\
\text { tujuannya karena aksi } 212 \text { tersebut telah } \\
\text { menemukan titik terang, yakni } \\
\text { ditangkapnya Basuk Tjahja Purnama } \\
\text { (Ahok) menjadi tersangka dari dugaan } \\
\text { kasus penistaan surat AL-Maidah ayat } 51\end{array}$ \\
\hline 02 & $\begin{array}{l}\text { Memperkirakan } \\
\text { masalah atau sumber masalah } \\
\text { (Diagnose cause) }\end{array}$ & $\begin{array}{l}\text { Pada talk show Indonesia Lawyer } \\
\text { Club, perdebatan timbul dikarenakan } \\
\text { menurut narasumber Dedy Siregar pada } \\
\text { acara Indonesia Lawyer Club (ILC) reuni } \\
212 \text { sara dengan gerakan politik. Hal ini } \\
\text { dikarenakan banyaknya tokok politik yang } \\
\text { hadir mengikuti reuni } 212 \text { tersebut serta } \\
\text { dianggap mubazir, dikarenakan transaksi } \\
\text { dana untuk perhelatan tersebut digadang- } \\
\text { gadang mencapai Rp4 milliar. }\end{array}$ \\
\hline
\end{tabular}




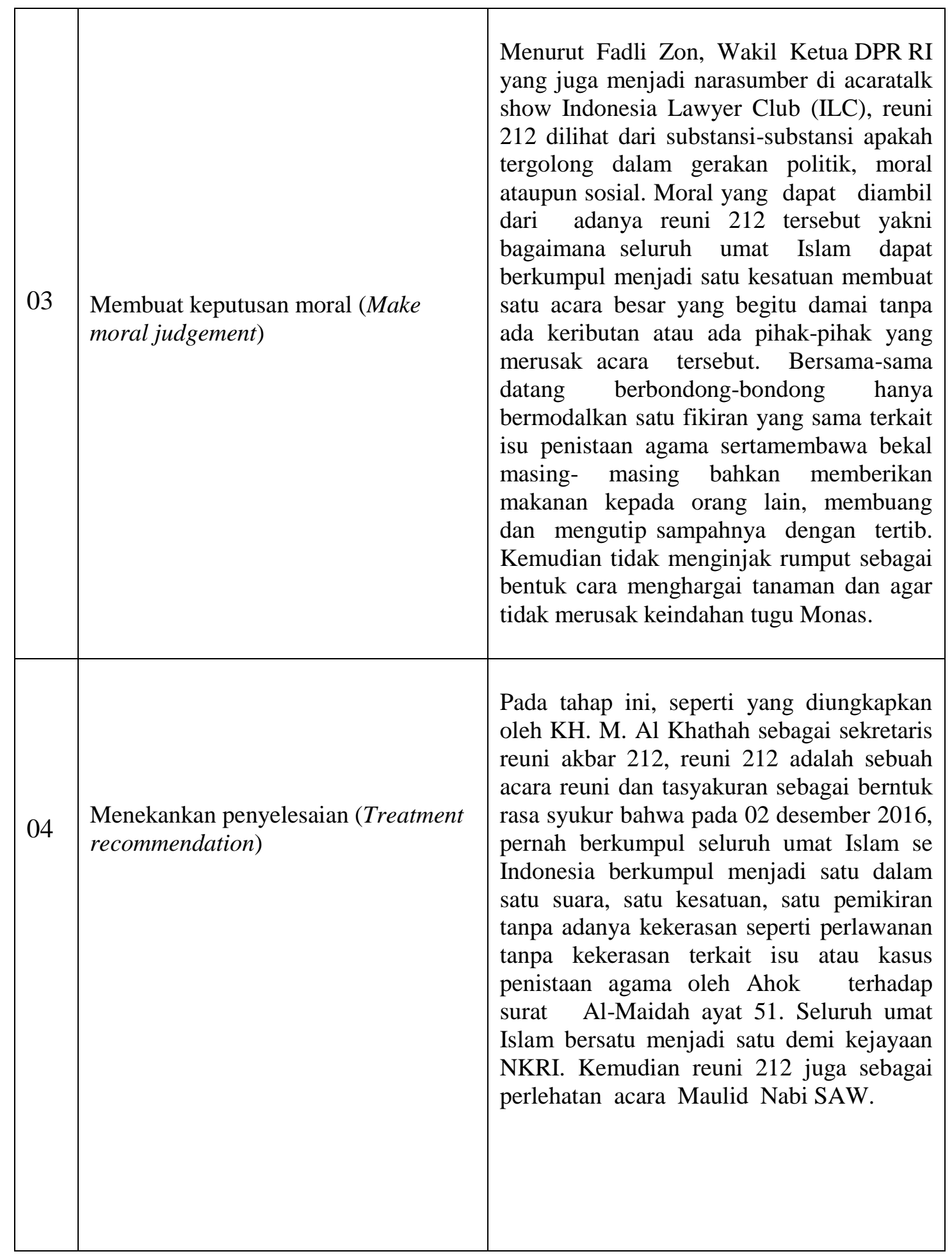

\section{Kesimpulan}

Dari hasil analisis framing Robert N. Entman dengan 4 perangkat framing acara talk show Indonesia Lawyer Club (ILC), maka penulis menarik kesimpulan yakni sebagai berikut :

Reuni 212 yang diadakan di Tugu Monas pada tanggal 02 Desember 2017 menimbulkan banyak perdebatan. Perdebatan timbul dikarenakan adanya pro dan kontra terkait perlu tidaknya diadakan Reuni 212 tersebut.Indonesia Lawyer Club mengupas perdebatan tersebut agar menemukan solusi jawaban. Reuni 212 sudah direncanakan secara terorganisasi jauh sebelum diadakannya kegiatan 
tersebut. Tujuan diadakan Reuni 212 adalah mengumpulkan kembali masyarakat yang mengikuti Aksi 212 sebagai bentuk aksi propaganda positif yang dilaksanakan masyarakat umat Islam bahwa ini adalah sebuah kebenaran dan menimbulkan rasa kepercayaan yang begitu besar.

Masyarakat yang berkumpul adalah masyarakat yang memiliki pandangan yang sama terkait isu penistaan agama oleh Basuki Tjahaja Purnama (Ahok) menjadi satu kesatuan demi kejayaan NKRI. Perdebatan pro dan kontra muncul karenak Reuni 212 tidak perlu diadakan karena keinginan masyarakat muslim pada kasus Ahok sudah tercapai. Isu yang berkembang untuk mengadakan kegiatan tersebut, maka panitia mengunpulkan dana sebanyak 4 milliar rupiah. Tentunya ini tidaklah dana yang sedikit untuk sebuah kegiatan reuni yang maksud dan tujuannnya jelas tercapai. Dalam hal ini, yang terjadi adalah politik identitas yang manaa berpusat pada politisasi identitas bersama atau perasaaan "kekitaan" yang menjadi basis utama perekat kolekivitas kelompok. Pada Reuni 212, reuni dibentuk oleh panitia penyelenggara sebagai bentuk rasa nyukur kepada Allah SWT karena kasus penistaan agama yang mengaitkan Gubernur DKI Jakarta Ahok telah menemui titik terang serta sebagai bentuk rasa persatuan dan tasyakuran atas bersatu dan bertemunya masyarakat muslim tanpa adanya kelompok-kelompok tertentu yang menggangu dan juga sebagai bentuk menjaga momentum aksi 212.

\section{Daftar Pustaka}

Cangara, Hafied. (2014). Pengantar Ilmu Komunikasi. Jakarta: PT. Raja GrafindoPersada (2012). PengantarIlmuKomunikasi. Jakarta: PT. Raja GrafindoPersada (2004). Pengantar Ilmu Komunikasi (Cetakan Keempat). Jakarta: PT. Raja Grafindo Persada.

Cangara, Hafied. (2003). Pengantar Ilmu Komunikasi. Jakarta: PT. Raja Grafindo Persada (2002). Pengantar Ilmu Komunikasi. Jakarta: KencanaPrenada Group.

Effendy, Onong Uchjana. (2011). Ilmu Komunikasi Teori dan Praktek. Bandung: PT Remaja Rosdakarya (2005). Dinamika Komunikasi, Jilid III, Bandung: Remaja Rosdakarya.

Elvinaro, Ardianto. (2014). Komunikasi Massa Suatu Pengantar, Bandung: Simbiosa Rekataman media. (2004). Komunikasi Massa, Bandung: Simbiosa Rekatama Media.

Eriyanto. (2010). Analisis Framing, Konstruksi, Ideologi Dan Politik Media, Jakarta: Rineka Cipta (2002). Analisis Framing, Yogyakarta: LKIS

Kriyantono, Rakhmat. (2006). Teknik Riset Komunikasi. Jakarta. Kencana.

Mulyana, Deddy. (2005). Ilmu Komunikasi Suatu Pengantar. Bandung: Remaja Rosdakarya.

McQuail, Dennis. (2005). Teori Komunikasi Massa. Yogyakarta. Pustaka Pelajar.

Nawawi. (2005). Penelitian Penerapan, Yogyakarta: Gajah Mada University. 